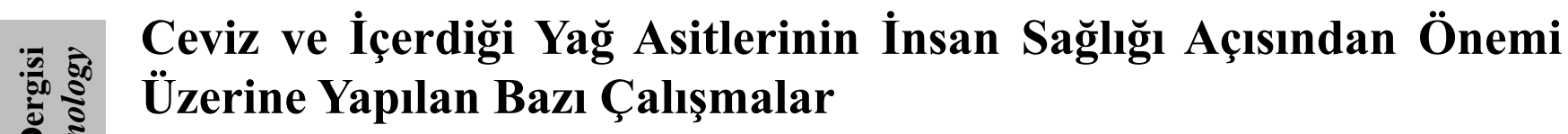 \\ Mikdat ŞIMSŞEK ${ }^{1}$ Ersin GÜLSOY² \\ ÖZET: Sert kabuklu meyveler içinde yer alan ceviz (Juglans regia L.), içerdiği besin değeri ve insan sağlı̆̆ üzerindeki olumlu etkilerinden dolayı günümüzde önemi giderek artan önemli bir meyve türüdür. Uzun yıllar süren bilimsel çalışmalar, cevizin insan vücudunu pozitif olarak etkileyen besin içerikleri ile yüklenmiş olduğunu ortaya çıkarmıştır. Ceviz içeriğinde bulunan zengin omega-3 esasinyel yağ asitlerinin sağlık açısından birçok faydaları tespit edilmiş ve bu yüzden, ceviz meyvesinin içerdiğgi yağ ve yağ asitleri konusunda pek çok araştırma yapılmıştır. Bu makale ceviz tüketiminin ve içerdiği yağ asitlerinin insan sağlığına faydaları konusunda yapılan bilimsel çalışma sonuçlarının derlenmesini amaçlamaktadır.
}

Anahtar Kelimeler: Beslenme, ceviz, insan sağlı̆̆ı, yağ asitleri

\section{The Important in Terms of Human Health of the Walnut and the Fatty Acids and Some Studies on This Subject}

\begin{abstract}
Due to its positive effects on nutrient content and human health, walnut (Juglans regia $\mathrm{L}$.) located in nuts is a special species which is increasingly important_nowadays. The scientific studies that continue for many years have been revealing that it is loaded with rich nutrient content positively affecting human body of walnut. Due to high fat content this species is very nutritive. In particular, the rich omega-3 essential fatty acids of walnut content have many benefits in terms of the health. Therefore, many studies have been made on fat and fatty acids of walnut up to now. The aim of this article was to evaluate the results of scientific studies about walnut consumption and its fatty acid content on the benefits effects of human health.
\end{abstract}

Keywords: Walnut, fatty acids, human health, nutrition

Dicle Üniversitesi, Ziraat Fakültesi, Bahçe Bitkileri Bölümü, Diyarbakır, Türkiye

Iğdır Üniversitesi, Ziraat Fakültesi, Bahçe Bitkileri Bölümü, Iğdır, Türkiye

Sorumlu yazar/Corresponding Author: Mikdat ŞIMMŞEK, mikdat.simsek@dicle.edu.tr 


\section{GİRIŞ}

Dünya'da yetiştiriciliği yapılan en eski sert kabuklu meyve türlerinde biri olan ceviz (Juglans regia L.) Türkiye'nin de birçok ilinde yetiştirilmektedir (Şen, 1986; Simsek, 2010; Akça, 2012;). Bu bağlamda ülkemiz, ceviz üretimi açısından yeryüzünün en önemli ülkeleri arasında yer almaktadır. 2012 yılı FAO verilerine göre dünya ceviz üretimi yaklaşık 3 458045 ton gerçekleşmiştir. Dünya'da ceviz üretimi yapan ülkelerin üretim miktarları incelendiğinde, Çin, İran ve Amerika Birleşik Devletlerinin sırasıyla 1700000,453980 ve 420000 tonluk üretimleriyle ilk üç sırayı paylaşdığ , Türkiyenin ise 212140 tonluk üretimi ile dördüncü sırada yer aldığ 1 görülmektedir. (FAO, 2012).

Ceviz yetiştiriciliğinin Anadolu'da yaygın olmasının iki gerekçedenkaynaklandığı belirtilmektedir. Birincisi, Akdeniz ülkelerinde yaşayan insanların diyeti arasında önemli bir konuma sahip olması, ikincisi ise uzun süre depolanabilme özelliğinden dolayı insanoğlunun yaratılışından bu yana günlük diyetinin mühim bir parçası haline gelmiş olmasıdır (Amaral et al., 2003).

Milattan sonra on altıncı ve on yedinci yüzyıllarda pek çok bitki insanın beden azalarına benzetilmiş ve insanın beden azalarında vuku bulan hastalıkların tedavisinde değerlendirilmiştir. Bunların içinde önemli bir konuma sahip olan ceviz, baş rahatsızlıkların tedavisinden, hafizanın güçlenmesine, duygu, his ve heyecanın kontrol altına alınmasıdan bazı cilt hastalıklarının tedavisine kadar birçok hastalığın tedavisinde ilaç olarak işlev görmüştür. Özellikle, Asya kıtasında yaşayan insanların kültüründe ceviz halen beynin gidası olarak tüketilmektedir (Ergun ve Sütyemez, 2008).

Son 30 yıldan beri yapılan araştırmalar; insanların beslenme alışkanlıkları ile hastalıklar ve sağlıklı yaşamaları arasında bir ilişki olduğunu ortaya çıkarmıştır. Çok iyi bilinen bazı hastalıklarla beslenme arasındaki ilişkiler araştırılırken en fazla sorgulanan gıda bileşeni/gıda maddesi yağlar olmuştur. Örneğin, son yıllarda yürütülen araştırmalarda cevizdeki yağ asitlerinin doymuş veya doymamış yapıda olmaları, kolesterol ve esansiyel yağ asidi içerikleri gibi özellikler üzerinde durulmaktadır (Kayahan, 2009).
İnsan sağlığına oldukça yararlı olan ceviz, daha çok tekli doymamış yağları içermekle beraber, günlük yă̆ ihtiyacımızın bir parçası olan omega-3 ve omega-6 gibi çoklu doymamış yağ asitlerince de oldukça zengindir (Amaral et al., 2003). Bu bağlamda, Ceviz tiplerinin içerdikleri yağ asitleri üzerine yapılan bir araştırmada linoleik asit içeriği \% 50.24-60.60 arasındaki değer ile en yüksek oranda belirlenmiş, bunu sirasıyla, \% 20.70-28.33 arasındaki değer ile oleik asit ve \% 10.93-15.04 arasındaki değer ile linolenik asit takip etmiştir. Ayrıca, çalışmada \% 22.17-29.73 arasında tekli doymamış yağ asitleri ve \% 4.00-7.86 arasında doymuş yağ asitleri elde edilmiştir (Simsek, 2016). Simopoulous, (2004) yaptığ bir çalışmada cevizde çoklu doymamış yağ asitlerinden Omega-3 ve Omega-6'nın sirasıly $9.081 \mathrm{~g} 100 \mathrm{~g}^{-1}$

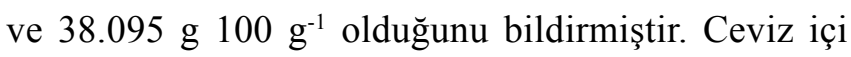
bileşiminde içerdiği yağ asitlerinden başka yağda çözünen vitaminlerden $\mathrm{A}$ ve $\mathrm{E}$, suda çözünenlerden B1, B2, C, folik asit, pantotenik asit ve niasin, minerallerden; demir, magnezyum, bakır, çinko ve fosfor da içermektedir (Anonymous, 2005). Bu mineral maddelerin insan sağlığına pek çok faydaları bulunmaktadır. Araştırmalarda kalsiyumun diş ve kemik gelişmesinde önemli rolü olduğu; magnezyum yetersizliğindehipertansiyon, koroner kalp hastalıkları, diabet, astım ve migren ağrıları görüldüğ̈̈; çinkonun insan vücudunda bol miktarda bulunan besleyici elementlerden biri olduğu ve kas ve kemiklerin \% 85 'inde, deri ve akciğerin \% 11'inde bulunduğu; manganın sinir sistemi ve kalp fonksiyonunda önemli fizyolojik rol oynadığ ; demirin organizmanın normal ve sağlıklı çalışması için önemli olduğu; bakırın ise vücuttaki bir çok enzimin çalışması için kofaktör olarak görev alan bir iz element olduğu bildirilmiştir (Bryant et al., 1999; Tapiero et al., 2003; Tapiero and Tew, 2003; Touyz, 2004; Ding et al., 2014; Zhai et al., 2014).

Ceviz içi ayrıca; \%13.6-22.3 oranında protein, \%56.4-70.6 oranında yă ve \% 2 civarında kül içermektedir. (Şahin ve Akbaş, 2001).

$\mathrm{Bu}$ makalede geçmişten günümüze kadar cevizin insan sağlığına yönelik yararlarının vurgulanması ve cevizdeki yağ asitleri ile ilgili yapılmış bazı önemli bilimsel araştırma sonuçlarının derlenmesi amaçlanmıştır. 


\section{CEVIZİN INSAN SAĞLIĞI AÇISINDAN FAYDALARI}

1. Kanser, günümüzün en tehlikeli hastalıklardan birisidir. Bu hastalık, insan hücrelerindeki DNA'nın zararlanmas1 neticesinde bu hücrelerin kontrolsüz veya anormal bir şekilde büyümesi ve çoğalması sonucu ortaya çıkmaktadır (Anonim, 2016a). Parkinson hastalığı, beynin alt kısımlarındak gri cevher çekirdeklerinin bozukluğuna bağlı bir sinir sistemi hastalığıdır (Anonim, 2016b). Alzheimer hastalığ 1 ise insanın günlük hayatsal aktivitelerinde azalma ve bilişsel yeteneklerin bozulması sonucu ortaya çıkan bir hastalık olarak tanımlanmaktadır (Anonim, 2016c). Reither et al., (2005) cevizin antioksidan içeriği sebebiyle kanser riskini azaltabilme, kardiyovasküler ve sinir sistemine zarar veren Parkinson ve Alzheimer gibi çok kuvvetli hastalıkların gelişimini erteleyebilme veya azaltabilme gibi bir özelliğinin olduğunu vurgulamışlardır.

2. İnsan beyninde salgılanıp kişinin biyolojik saat ritmini ayarlanmasına sebep olan ve insanın uyku düzeninin sağlanmasından sorumlu tutulan hormon Melatonin hormonudur (Anonim, 2016d). İnsan vücudunun kullanıma hazır melatonin formu cevizde mevcuttur. $\mathrm{Bu}$ hormonun üretimi vücut yaşlandıkça azalmakta ve bu azalma sadece uyku düzensizliğine değil muhtemelen antioksidan eksikliği ile de ortaya çıkan serbest radikallere bağlı hastalıkların da artmasına sebep teşkil edebilmektedir. Ceviz tüketiminin kandaki melatonin seviyesini arttırdığ 1 ve uyku düzensizliği gibi rahatsızlıkların ortadan kalkmasına katkı sağladığı ifade edilmiştir (Reiter et al., 2005).

3. Ceviz içerdiği yüksek miktardaki omega-3 yağ asitleri ile bir beyin gidasıdır. Bir insan beyninin yaklaşık \% 60'nın yapısal karakterli yağlardan meydana geldiği, beynin düzgün ve kesintisiz çalışabilmesi için bu yağlara özellikle de omega-3 yağ asidine ihtiyaç duyduğu belirtilmektedir (Stevens et al.,1995). Depresyon, çocuklarda dikkat eksikliği ve hiperaktiviteve beyin sinirlerindeki bozulma ile omega-3 tüketimi seviyesi arasında bir bağlantının olduğunu epidemolojik araştırmalar ile ispatlanmıştır (Stevens et al., 1996).

4. Diyetsel olarak 120 yıl boyunca 80000 kadın üzerinde yapılan bir araştırmada, haftada $30 \mathrm{~g}$ ceviz içi yiyenlerin \% 25 daha az safra taşı oluşturma riskine sahip olduğu belirtilmiştir Aynı araştırmada araştırıcılar, bunun sebebini tam olarak açıklayamadıklarını bununla beraber elde edilen sonucun cevizin yağ profilinden, fitosterollerden ve/veya magnezyum mineralinden kaynaklanabileceği ihtimalinin daha yüksek olduğunu rapor etmişlerdir (Tsai et al., 2004).

5. Bilim insanları, ceviz ile beynin fiziki yapısının yanı sıra, cevizdeki besinler ile beynin ihtiyacı olan vitaminlerin benzerliği arasındaki ilişkinin şaşırtıcı olduğunu belirtmişlerdir (Anonim, 2016f) Ancak, icra ettiği elektronik vazife açısından gümüş elementine ihtiyaç duyan tek organın beyin olduğunu söylersek, bu muhteşem benzerlik ve mükemmel yaratılış karşısında insanoğlunun tüyleri diken diken olacaktır (Anonim, 2016e). Bu bağlamda, insan beyninde bulunan gümüş elementinin, bütün meyveler içinde sadece cevizde bulunduğu, insan beyninin sağlıklı çalışması için bu elementin gerekli olduğu ve çocukların zeka gelişimini de olumlu yönde etkilediği araştırmalarla ortaya konulmuştur(Şimşek, 2015).

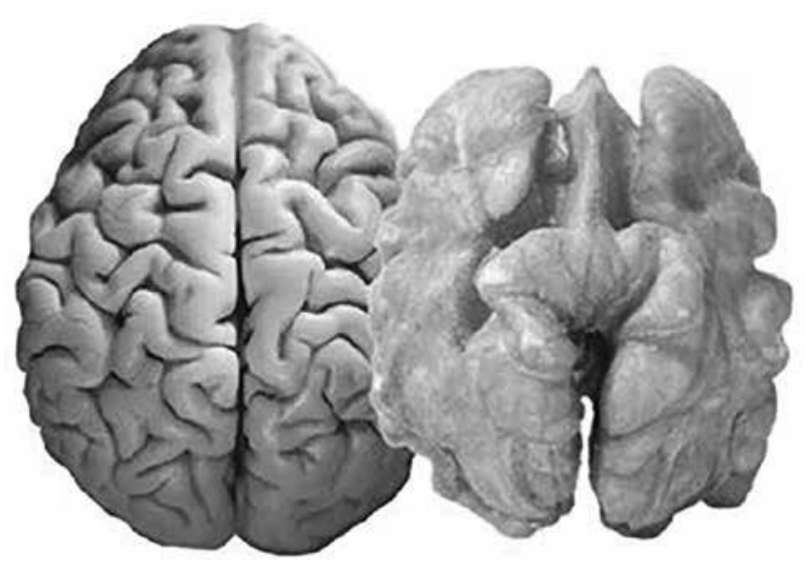

Şekil 1. Ceviz içi ve beynin görüntüsü (Anonim, 2016f).

6. Tip 2 diyabet şeker (Diyabet) hastalıkları içinde en tehlikelisi olan diyabet türüdür. Bu hastalık, insülin etkisine karşı direnç gelişmesi ya da insülin duyarlığının azalması ile insülin sentezi ve salgılanmasının göreceli olarak azalması ya da tamamen ortadan kalkması ile ortaya çıkmaktadır (Anonim, 2016g). Yapılan bir araştırmada, günde $30 \mathrm{~g}$ ceviz yiyen Tip 2 diyabet hastalarının kolesterol profilinin iyileştiği gözlenmiştir. Araştırıcılar, yaş ortalaması 58-59 arasında olan erkek ve kadınları 3 gruba ayırıp her bir gruba 3 farklı diyet uygulamışlardır. Birinci gruptakilere diyette aldıkları 
kalorilerinin \% 30'u yağdan, ikinci gruptakilere diyette biraz daha farklı yağ çeşidi kullanmak suretiyle kalorilerinin \% 30'u yine yağdan sağlanmış ve üçüncü gruptakilere ise diyette ikinci diyete ek olarak 30 g ceviz eklenmiştir. Altı ay sonraki değerlendirme sonuçlarında, ceviz içeren diyete tabi tutulan kişilerin yüksek yoğunluklu lipoprotein (HDL)/toplam kolesterol değerleri diğer diyet gruplarına göre fazla çıkmıştır. Ayrıca, bu grubun düşük yoğunluklu lipoprotein (LDL) kolesterol içeriklerinin\% 10 azaldığ 1 tespit edilmiştir. Bunun nedeninin ise büyük bir olasılıkla cevizde yüksek oranda bulunan omega-3 asitlerinden kaynaklandığ ifade edilmiştir (Tapsell et al., 2004).

7. Tekli doymamış yağlarca zengin olan cevizi düzenli ve yeterli düzeyde tüketen insanlarda, yüksek kolesterol seviyesinde ve öteki kardiyovasküler risk faktörlerinde bir azalma gözlenmiştir (Savage et al., 1999). Örneğin, ceviz içerdiği omega-3 yağ asitleri sayesinde düzensiz kalp atışlarının engellenmesine, damarlarda daha az pihtılaşma özelliği olan kan tipinin üretimine ve yüksek yoğunluklu lipoprotein (HDL) kolesterol oranının düşük yoğunluklu lipoprotein (LDL) kolesterol oranına göre artmasına katkı sağlamaktadır (Tapsell et al., 2004). Omega-3 yağ asitleri, kolesterolün damarları tıkama aşamasında önemli bir belirtisi olan şiş ve kızarıklığın azalmasına sebep olmaktadır (Morgan et al., 2002). Ceviz, yüksek tansiyonla ilişkilendirilen önemli miktarda esansiyel bir amino asit çeşidi olan L. arginin de içermektedir. Özellikle vücudun çok çalışan kan damarlarında bu amino asit, nitrik okside çevrilmekte ve nitrik oksitte kan damarların iç tarafının pürüzsüz ve düzgün olmasına katkı sağlayarak kan damar sisteminin rahatlamasını sağlamaktadır. $\mathrm{Bu}$ nedenle, cevizin kardiyovasküler yararlarının daha da fazla olduğu vurgulanmıştır (Fukuda et al., 2003).

8. On yetişkin insan üzerinde yapılan bir araştırmada, günlük 4 tane ceviz tüketmenin kandaki omega-3, alfa-linoleik asit (ALA) ve eikosapentaenoik asit (EPA) seviyelerini önemli ölçüde artırdığ 1 belirtilmektedir. Yine bir araştırmada günde 3-5 tane ceviz yiyen yetişkinlerin kanındaki koruyucu omega-3 seviyelerinin iyileştiği belirlenmiştir (Marangoni et al., 2007). Ayrıca, günde ortalama dört tane ceviz yemenin insan sıhhatine oldukça faydalı olduğu belirtilmiştir (Şimşek, 2015).

9. Cevizin en dış kısmını kaplayan yeşil kabuğunun sıkılmasıyla elde edilen su kaynatıldıktan sonra sivilcelere sürüldüğünde, sivilcelerin yok olmasina sebep olmaktadır. Taze veya kuru ceviz yaprağı incecik kıyıldıktan sonra kaynatılıp lapa haline getirilirse, bu lapa sivilcelere, yaralara ve şişmiş salgı bezlerinin iyileşmesine katkı sağlamaktadır. Cevizden elde edilen yağın, boğaz ağrısının tedavisinde etkili olduğu vurgulanmıştır. Ayrıca, cevizin yapraklarından, yeşil kabuğundan ve erkek çiçeklerinden elde edilen ceviz merhemi egzama, akıntılı yara, çıban yarası ve hatta cüzzam benzeri deri hastalıklarının iyileşmesine sebep olmaktadır (Şen, 2011).

10. Sert kabuklu meyve türlerinden olan cevizin kolesterol üzerine iyileştirici etkisinin yanı sıra, damar kalp hastalıklarındaki riski azalttığıda belirtilmiştir. Araştırıcı, ceviz yağı içeren diyetin LDL kolesterol seviyesini ve karbon reaktif protein seviyesini de azaltığını tespit etmiştir. Karbon reaktif protein miktarının azalması ise damar tıkanıkları ve kalp hastalıklarının azalmasına sebep olmaktadır (Feldman, 2002).

11. Yukarıda belirtilen faydaları dişında, tarih boyunca insanlar, bazı hastalıkların tedavisinde cevizi kullanmışlardır. Ceviz içinin taş dökücü, idrar söktürücü olduğu, astım, kronik öksürük ve kansızlığa iyi geldiği, hamilelik boyunca kusmayı önlediği, kilo aldırıcı ve sakinleştirici olarak kullanıldığı belirtilmiştir. Ayrıca ceviz içinden elde edilen yağ; kolit ağrılarında ve adet düzensizliklerinde, saç kuruluğu, kepeklenme ve baştaki yaraların tedavisinde değerlendirilmektedir. Suda kaynatılan cevizin meyve kabuğu bağırsak iltihabına ve mantar hastalıklarına iyi gelmektedir. Cevizin yeşil kabuğu kansızlı̆̆ı, mide iltihaplarını, apseleri, göz kapagı iltihaplarını gidermete baş ve vücut bitlerini ve bağırsak kurtlarını öldürmekte, aynı zamanda akne ve uçukları tedavisinde de kullanılmaktadır. Ayrıca, ceviz yapraklarının el ve ayak terlemelerinin azaltılmasında da, değerlendirildiği belirtilmektedir (Yiğit ve ark., 2005).

\section{CEVIZ YĂ̆ ASITLERİ ÜZERINNE YÜRÜTÜLEN BAZI ÇALIŞMALAR}

Willet et al., (1995) cevizin çoklu doymamış yağ asitleri bakımından oldukça zengin olduğunu belirtmiş ve cevizin yüksek oranda omega-3 ve omega-6 yağ asitleri içerdiğinden dolayı sert kabuklu meyveler içersinde öne çıktığını ifade etmişlerdir.

Zwarts and Savage, (1999) ceviz yağındaki oleik asit, linoleik asit ve linolenik asitlerin bulunuş 
oranlarının ekonomik ve besin değeri için önemli kriterlerden olduğunu belirtmişlerdir. Ayrıca düşük linoleik ve linolenik asit içerikli yağların daha uzun raf ömrüne sahip olduğunu, buna karşın çoklu doymamış yă asitlerinin yüksek oranlarının, sağlık açısından yararlı olması nedeniyle daha çok tercih edildiğini, yüksek linoleik asit içeriğine sahip ceviz yağının kızartmalarda yanmaya eğilim göstermesi sebebiyle uygun olmadığını, fakat ekmek, kek ve bisküvi üretiminde kullanılabileceğini vurgulamışlardır.

Almario et al., (2001) yaptıkları klinik çalışmalarda cevizin içerdiği doymamış yağ asitleri ve liflerin kandaki triasilgliserol ve kolesterol konsantrasyonunu azaltarak plazma yağların düzenlenmesine etki ettiğini ve cevizin kalp sağlığına koruyucu etki yapmasının nedenleri arasında özellikle cevizdeki yağ asit profili ve polifenol zenginliğininden kaynakandığı vurgulamışlardır (Anderson et al., 2001).

Cevizdeki çoklu doymamış yağ asitlerinin kalpdamar hastalıklarını önlemede antienflamator ve antihipertensif etkiye sahip olduğu, özellikle kandaki yağ seviyesini azalttığ engellediği, Omega 3 ve Omega 6'nın esansiyel yağ asitleri olduğu ve vücut tarafından sentezlenmemeleri nedeniyle gidalar ile alınmalarının zorunlu olduğu ifade edilmiştir (Carrero et al., 2004; Heidal et al., 2004). Bu yüzden, sahip olduğu bu özellik nedeniyle cevizin insanlar tarafından tüketilen vazgeçilmez bir besin olduğu vurgulanmıştır.

Ceviz meyvelerinin toplam yă ve yağ içerikleri üzerine yürütülen bir çalışmada ceviz çeşitlerindeki yağ oranının \%65.00-70.00 arasında değiştiği ve yağ asitleri içinde oleik asitin \%22.6327.27, linoleik asidin \%49.93-54.41, linolenik asidin \%14.32-17.82 ve palmitik asidin \%5.615.82 arasında değiştiği ifade edilmiştir (Dogan and Akgul, (2005).Ozkan and Koyuncu, (2005) ise ceviz örneklerinin toplam yağ içeriğini \%61.9770.92 olarak tespit etmişler ve yağ asitleri içinde oleik asitin \%21.18-40.20, linoleik asitin \%43.9460.12, linolenik asitin \%6.91-11.52, palmitik asitin \%5.24-7.62 ve stearik asitin ise \%2.56-3.67 arasında değiştiğini bildirmişlerdir. Patel, (2005), Cevizin, çoklu doymamış yă asitlerinin uygun oranda (4:1) içermesinin fonksiyonel bir gida olarak tanımlanmasına katkı sağladığını bildirmiştir.
Ünver ve Çelik, (2005) inceledikleri ceviz tiplerinin yağ oranlarının \%47.84-66.74 arasında linoleik asitin $\% 41.13-61.15$, oleik asitin \%22.39-49.12, palmitik asitin \%6.01-10.21 ve stearik asit oranının ise \%2.174.99 arasında değiştiğini tespit etmişlerdir.

Pereira et al., (2008) tarafından 6 ceviz çeşidi üzerinde yürütülen bir çalışmada en yüksek proksimat bileşeni \%78.83-82.14 ile yağın oluşturduğu ve yağ asitleri içinde ortalama \%60.30 ile linoleik asitin en yüksek değere sahip olduğu, bunu sırasiyla oleik, linolenik ve palmitik asitlerin izlediği bildirilmiştir. Cevizi fonksiyonel yapan en önemli bileşenlerinden birinin içerdiği yağlar olduğu ve özellikle yağın, oransal olarak çoklu doymamış yağ asitlerince zengin olmasının beslenmedeki önemini daha da arttığ belirtilmişdir (Lavedrine et al., 2009). Ayrıca araştırıcılar cevizde ortalama \%72 çoklu doymamış yağ asidi, \%18 tekli doymamış yağ asidi ve \%10 ise doymuş yağ asidi içeriği tespit etmişlerdir.

Ozcan, (2009) ceviz genotipleri üzerinde yaptı̆ğ bir araştırmada $\% 6.4$ palmitik, $\% 13.4$ oleik, $\% 55.3$ linoleik ve \%8.7 linolenik asit içeriği tespit etmiştirBakkalbaşı ve ark., (2010) ceviz çeşitlerindeki doymamış yağ asidi oranının \%90.21-92.03 ve çoklu doymamış yağ asidi oranının ise \%61.83-75.32 arasında değiştiğini saptamışlardır.

Mart'ınez et al., (2010) cevizin kimyasal kompozisyonu içinde yağın en yüksek oranda değere sahip olduğunu ve doymamış yağ asitleri içinde en fazla linoleik asitin bulunduğunu ve bunu sirasılyla oleik ve linolenik asitlerin takip ettiğini belirtmişlerdir.

Muradoglu et al., (2010) tarafindan yürütülen çalışmada ceviz genotiplerinin ortalama yağ içeriği \%58.2 olarak saptanmış ve bütün genotiplerde doymuş yağ asitlerinin hem tekli, hem de çoklu doymamış yă asitlerinden daha az olduğu vurgulanmıştır. Ayrıca tanımlanan yağ asitleri içinde, linoleik asitin \%50.5866.60, oleik asitin \%14.88-28.71, linolenik asitin \%9.16-6.42, diğer asitlerin ise çok az miktarlarda olduğu bildirilmiştir. Özrenk ve ark., (2011) ise ceviz genotiplerinde \%4.98-6.77 palmitik asit, \%0.050-0.12 palmitoleik asit, \%1.88-3.93 stearik asit, \%15.90-40.69 oleik asit, \%40.95-59.98 linoleik asit, \%8.92-17.81 linolenik asit, $\% 0.17-0.27$ behenik asit ve $\% 0.02-0.17$ arasında araşidik asit tespit etmişlerdir. 
Beyazit and Sumbul (2012) tarafindan yürütülen çalışmada ceviz tip ve çeşitlerinin \%6.98-8.77 palmitik asit, \%19.33-36.76 oleik asit, \%41.55-59.89 linoleik asit, \%8.44-11.0 linolenik asit ve \%3.22-4.99 steraik asit içerdikleri tespit edilmişdir.

Yerlikaya et al., (2012) ceviz genotip ve çeşitleri üzerine yaptıkları bir araştırmada en yüksek bileşenini \%61.32-69.35 ile yağ $ı n$ oluşturduğu ve yağ asitleri içinde \%17.90-33.35 oleik asit, \%43.15-60.20 linoleik asit, \%9.98-13.00 linolenik asit, \%5.21-8.40 palmitik asit ve \%2.36-4.25 stearik asit bulunduğu belirtilmiştir.

Simsek, (2016) tarafından yürütülen bir çalışmada cevizde en fazla bulunan yağ asidinin linoleik asit olduğu ve onu sırasıyla oleik ve linolenik asitin takip ettiği belirtilmiştir. Linoleik asitin \%50.24-60.60, oleik asitin \%20.70-28.33, linolenik asidin \%5.04-10.93, palmitik asidin \%1.80-5.53, stearik asidin \%1.17-2.22, doymuş yağ asitlerinin \%4.00-7.86, tekli doymamış yă̆ asitlerinin \%22.17-29.73, çoklu doymamış yağ asitlerinin \%62.73-71.43, çoklu doymamış yağ asitleri/ doymuş yağ asit oranın ise 8.14-17.11 arasında değiştiği saptanmıştır. Araştırıcı, cevizde bulunan yağ asidi oranının ceviz tip ve çeşitlerine, gübrelemeye, sulamaya, coğrafik alanlara, ekolojik koşullara, hasat zamanına ve ağaçta bulunan meyvenin pozisyonuna bağlı olarak değişkenlik gösterebileceğini vurgulamıştır.

\section{SONUÇ}

Sert kabuklu meyveler içinde yer alan ceviz hem beslenme açısından yüksek bir değere sahip hem de tıbbi tedavilere destekleyici olarak meyvesi, kabuğu, yaprağ 1 kullanıldığı için fonksiyonel bir gida olarak tanımlanmaktadır. İnsan beyninin sağlıklı bir şekilde çalışıp gelişebilmesine büyük katkısı olan esansiyel yağ asitleri, cevizde bol miktarda bulunmaktadır. Daha dengeli ve sağlıklı beslenebilme için ceviz tüketimine önem verilmesi gerekmektedir. Ayrıca ceviz meyvesinin yüksek oranda yağ asitleri içerdiği ve bunların faydaları konusunda gerekli bilinç oluşturulmalıdır. Özellikle cevizde yüksek oranda bulunan omega-3 yağ asitlerinin insan sağlığına faydalarına yönelik araştırmalar; kanser, depresyon, alzheimer, diyabete kadar değişik alanlarda devam etmektedir. Bu araştırmalar devam ettikçe insanda omega-3 ihtiyacının önemi daha da iyi anlaşılacaktır. Bu nedenle cevizdeki yağ asitleri ile ilgili bilimsel çalışmalara gerekli önem verilmeli ve bu çalışmalar ilgili kuruluşlarca desteklenmelidir.

\section{KAYNAKLAR}

Akça, 2001. Ceviz Yetiştiriciliği. Arı Ofset Matbaası. Tokat. 356 s.

Almario RU, Vonghavaravat V, Wong R, Karakas S, 2001. Effect of walnut consumption on plasma fatty acids and lipoproteins in combined hyperlipidemia. American Journal of Clinical Nutrition. 74: 72-79.

Amaral JS, Casal S, Pereira JA, Seabra RM, Oliveira BPP, 2003. Determination of sterol and fatty acid compositions, oxidative stability, and nutritional value of six walnut (Juglans regia L.) cultivars grown in Portugal. Journal of Agricultural and Food Chemistry, 51 (26): 7698-7702.

Anderson KJ, Teuber SS, Gobeille A, Cremin P, Waterhouse AL, Steinberg FM, 2001. Walnut polyphenolics inhibit in vitro human plasma and LDL idation. The Am. J. Nutr. 131: 28372842 .

Anonim, 2016a. https://tr.wikipedia.org/wiki/Kanser

Anonim, 2016b. https://tr.wikipedia.org/ wiki/ Parkinson hastal $\% \mathrm{C} 4 \% \mathrm{~B} 1 \% \mathrm{C} 4 \% 9 \mathrm{~F} \% \mathrm{C} 4 \% \mathrm{~B} 1$

Anonim, 2016c. https://tr. wikipedia. org/ wiki/Alzheimer_hastal\% $\mathrm{C} 4 \% \mathrm{~B} 1 \% \mathrm{C} 4 \%$ 9F\% C4\%B1

Anonim, 2016d. http://www.1organik.com/melatonin-icerenyiyecekler.html

Anonim, 2016e. http://www.gidahareketi.org/beyin-dostu-gida-ceviz-624-yazisi.aspx

A non im $2016 \mathrm{f} . \mathrm{https}: / / \mathrm{www}$.google.com.tr/ search? $\mathrm{q}=$ ceviz $+\mathrm{ve}+$ beyin\&rlz $=\quad 1 \mathrm{C} 1 \mathrm{CHWA}$ trTR616TR617\& espv=2\&biw $=1517 \&$ bih=714\&source $=$ lnms\&tbm $=$ isch\&sa $=\mathrm{X} \& v e d=0$ ah UKE wjY 7aPQyv rMAhUBXRQKHTZGATsQ_AUIBigB\&dpr $=$.9\#imgrc $=$ U2ozm9yy UHPtMM\%3A.

Anonim, 2016g. https://tr.wikipedia.org/wiki/Diyabet

Anonymous, 2005. Walnut. www.forshang.org/012foodnhealth/ foodnhealthwalnute.htm

Bakklabaşı E, Yılmaz ÖM, Artık N, 2010. Türkiye'de yetiştirilen yerli bazı ceviz çesitlerinin fiziksel özellikleri ve kimyasal bileşenleri. Akademik Gıda 8 (1): 6-12.

Bayazıt S, Sumbul A, 2012. Determination of fruit quality and fatty acid composition of Turkish walnut (juglans regia) cultivars and genotypes grown in subtropical climate of eastern mediterranean region. International Journal of Agriculture \& Biology, 14 (3): 419-424.

Bryant RJ, Cadogan J, Weaver CM 1999. The new dietary reference intakes for calcium: implications for osteoporosis. J Am Coll Nutr 18(Sup5):406S-412S.

Carrero JJ, Baro L, Fonolla J, Gonzalez-Santiago M, Martinez-Ferez A, Castillo R, Jimenez J, Boza JJ, 2004.Cardiovascular effects of milk enriched with omega-3 polyunsaturated fatty acids, oleic acid, folic acid, and vitamins $\mathrm{E}$ and B6 in volunteers with mild hyperlipidemia. Nutrition. 2004;20: 521-527.

Lopez-Huertas E, 2004. Cardiovascular effects of milk enriched with $\omega-3$ polyunsaturated fatty acids, oleic acid, folic acid, and vitamins $\mathrm{E}$ and $\mathrm{B} 6$ in volunteers with mild hyperlipidemia. Nutrition 20(6): 521-527.

Dogan M, Akgul A, 2005. Fatty acid composition of some walnut (Juglans regia L.) cultivars from east Anatolia. Grasas y Aceites, 56 (4): 328-331.

Ding Y, Luo Y, Fu J, 2014. Effects of Mn (II) on peroxynitrite nitrifying fibrinogen. Bio-med Mater Eng 24(1):901-907. 
Ergun M, Sütyemez M, 2008. Sağlıklı bir yasam tarzı için ceviz. KSÜ Fen ve Mühendislik Dergisi, 11(1): 138-142.

FAO, 2012. http://faostat3.fao.org/download/Q/QC/E

Feldman EB, 2002. The Scientific evidence for a beneficial health relationship between walnuts and coronary heart disease. Journal of Nutrition, 132 (5): 1062S-1101S.

Fukuda T, Ito H, Yoshida T, 2003. Antioxidative polyphenols from walnuts (Juglans regia L). Phytochemistry, 63 (7): 795-801.

Heidal K, Lewis N, Evans S, 2004. Survey of omega 3 fatty acid intakes and omega 3 food selections in cardiac patients living in a section of the Midwestern United States. Nutrition Research, 24 (9): 741-747.

Kayahan M, 2009. Sağlıklı beslenme açısından trans yă̆ asitleri. II. Geleneksel Gidalar Sempozyumu, 27-29 May1s, 7-11, Van.

Lavedrine F, Zmirou D, Ravel A, Balducci F, Alary J, 1999. Blood cholesterol and walnut consumption: A Cross- Sectional Survey in France. Preventive Medicine. 28: 333-339.

Marangoni F, Colombo C, Martiello A, Poli A, Paoletti R, Galli C, 2007. Levels of the n-3 fatty acid eicosapentaenoic acid in addition to those of alpha linolenic acid are significantly raised in blood lipids by the intake of four walnuts a day in humans. Nutrition, Metabolism and Cardiovascular Diseases, 17(6): 457-461.

Mart'inez ML, Labuckas DO, Lamarque AL, Maestri DM, 2010. Walnut (Juglans regia L.): genetic resources, chemistry, byproducts. J Sci Food Agric, 90 (12): 1959-1967.

Morgan JM, Horton K, Reese D, Carey C, Walker K, Capuzzi DM, 2002. Effects of walnut consumption as part of a lowfat, low-cholesterol diet on serum cardiovascular risk factors. International Journal for Vitamin and Nutrition Research, 72 (5): 341-347.

Muradoglu F, Oguz HI, Yildiz K, Yilmaz H, 2010. Some chemical composition of walnut (Juglans regia L.) selections from Eastern Turkey. African Journal of Agricultural Research, 5(17): 2379-2385.

Ozcan MM, 2009. Some nutritional characteristics of fruit and oil of walnut (Juglans regia L.) growing in Turkey. Iran. J. Chem. Chem. Eng., 28 (1): 57-62.

Ozkan G, Koyuncu MA, 2005. Physical and chemical composition of some walnut (Juglans regia $\mathrm{L}$ ) genotypes grown in Turkey. Grasas y Aceites, 56 (2): 141-146.

Özrenk K, Kaya T, Balta F, Kan T, 2011. Van Gölü havzası cevizleri bazı pomolojik ve kimyasal özelliklerinin karşılaştırılması. Iğdır Üni. Fen Bilimleri Enst. Der. (Iğdır Univ. J. Inst. Sci. \& Tech.), 1(4): 15-22.

Patel G, 2005. Essential fats in walnuts are good for heart and diabetes. Journal of the American Dietetic Association, 105(7): 1096-1097.

Pereira JA, Oliveira I, Sousa A, Isabel CFR, Ferreira AB, Estevinho L, 2008. Bioactive properties and chemical composition of six walnut (Juglans regia L.) cultivars. Food and Chemical Toxicology, 46 (6): 2103-2111.

Reiter RJ, Manchester LC, Tan DX, 2005. Melatonin in walnuts: Influence on levels of melatonin and total antioxidant capacity of blood. Nutrition, 21(9): 920-924.

Savage GP, Dutta PC, McNeil DL, 1999. Fatty acid and tocopherol contents and oxidative stability of walnut oils. Journal of the American Oil Chemists Society, 76(9): 1059-1063.

Simopoulous AP, 2004. Health effects of eating walnuts. Food Reviews International, 20 (1): 91-98.
Stevens LJ, Zentall SS, Abate ML, 1996. Omega-3 fatty acids in boys with behavior, learning, and health problems. Physiology and Behavior, 59 (4/5): 915-920.

Stevens LJ, Zentall SS, Deck JL, 1995. Essential fatty acid metabolism in boys with attention-deficit hyperactivity disorder. American Journal of Clinical Nutrition, 62(4): 761768.

Simsek M, 2010. Selection of walnut types with high fruit bearing and quality in Sanliurfa population. International Journal of the Physical Sciences, 5(7): 992-996.

Simsek M, 2016. Chemical, mineral, and fatty acid compositions of various types of walnut (Juglans regia L.) in Turkey. Bulgarian Chemical Communications, 48(1): 66-70.

Şahin I, Akbaş H, 2001. Farklı yöre ve çesitlerden cevizlerin teknolojik özelliklerinin araştırılması. Türkiye 1. Ulusal Ceviz Sempozyumu, 5-8 Eylül,104-114, Tokat.

Şen SM, 1986. Ceviz yetiştiriciliği (1. Baskı). Samsun, OMÜ Basımevi.

Şen SM, 2011. Ceviz yetiştiriciliği ve besin değeri folklorü (4. Baskı). Ankara, ÜÇM Yayıncılık.

Şimşek M, 2015. Ceviz ve Beyin. http:// www.diyarbakirsoz. com/ yazarlar/ msimsek/ ceviz-ve-beyin- 8474 .

Tapiero H, Tew KD, 2003. Trace elements in human physiology and pathology: zinc and metallothioneins. Biomed Pharmacothe 57(9):399-411

Tapiero H, Townsend D, Tew K, 2003. Trace elements in human physiology and pathology. Copper. Biomed Pharmacother 57(9):386-398

Tapsell LC, Gillen LJ, Patch CS, Batterham M, Owen A, Bare M, Kennedy M, 2004. Including walnuts in a low-fat/modifiedfat diet improves hdl cholesterol-to-total cholesterol ratios in patients with type 2 diabetes. Diabetes Care, 27(12): 27772783.

Touyz RM 2004. Magnesium in clinical medicine. http:// www. ncbi. nlm. nih. gov/ pubmed/ 14977544.

Tsai CJ, Leitzmann MF, Hu FB, Willett, WC, Giovannucci EL, 2004. Frequent nut consumption and decreased risk of cholecystectomy in women. American Journal of Clinical Nutrition, 80(1): 76-81.

Ünver H, Çelik M, 2005. Ankara yöresi cevizlerinin (juglans regia 1.) seleksiyon yoluyla ıslahı. BAHÇE Ceviz 34 (1): 83-89.

Willet WC, Sacks F, Trichopolou A, 1995. Mediterranean diet pyramid: A cultural model for healthy eating. Am. J. Clin. Nutr., 61 (6): 1402-1407.

Yerlikaya C, Yucel S, Erturk U, Korukluoğlu M, 2012. Proximate composition, minerals and fatty acid composition of Juglans regia L. genotypes and cultivars grown in Turkey. Brezilian Archives of Biology and Technology, 55 (5): 677-683.

Yiğit A, Ertürk Ü, Korukluoğlu M, 2005. Fonnksiyonel bir gida: Ceviz. Bahçe Ceviz, 34 (1): 163-169.

Zhai M, Wang, Wang D, Xu J, Sh1 G, 2014. Comparative analysis of mineral elements and essential amino acids compositions in Juglans sigillata and J. regia Walnuts Kernels Not Bot Horti Agrobo, 42(1):36-42.

Zwarts J, Savage GP, 1999. Fatty New Zealand grown walnuts (Juglans regia L.). Int. J. Food Science \&Technology, 50 (3): 189-195. 
